\title{
繰り返し載荷を受ける長ほぞ差し込栓打ち仕口の弾塑性解析 ELASTO-PLASTIC ANALYSIS OF MORTISE-TENON JOINT WITH DOWEL SUBJECTED TO CYCLIC LOADING
}

\author{
栘 井 健 ${ }^{*}$, 錦田謙介**, 高木利 季*** \\ Takeshi MASUI, Kensuke NISHIKIDA and Toshiki TAKAGI
}

\begin{abstract}
We propose an incremental analysis method with a model considering compressive strain inclined to the grain and friction in a mortise-tenon joint with dowel to examine the hysteresis characteristics of the joint subjected to cyclic loading. We introduced a concept of apparent shear stiffness based on the Coulomb's friction into constitutive law. The analysis method can evaluate cyclic hysteresis characteristics of the joint with constitutive law based on material tests. We performed a bending test of a T-type specimen composed with a beam and a column, and confirmed validity of the proposed analysis method.
\end{abstract}

Keywords : Wooden framework, Joint, Compressive strain inclined to the grain, Friction, Elasto-plastic Analysis, Cyclic loading

木造軸組，仕口，めり込み，摩擦，弾塑性解析，繰り返し載荷

\section{1. はじめに}

伝統木造軸組構法の差鴨居骨組のように、大きな開口を有する構 造形式では、水平抵抗の多くを仕口におけるモーメント抵抗によっ て負担している。従って、伝統木造軸組の水平抵抗特性を把握する ためには仕口の構造特性の適切な評価が必要である。これまでにも、 仕口の構造特性を評価することを目的として、数多くの実験的、解 析的研究が実施されている。

前野、鈴木 1) は、架構全体の実大実験を実施し、横架材の曲げモ ーメント抵抗の重要性を指摘した。西村ら 2)は、柱 - 土台間の長ほ ぞ込栓打ち接合部を対象として、一定鉛直荷重下での水平繰り返し 載荷による接合部の曲げ実験を行い、接合部の力学モデルに関する 考察を行った。松本ら ${ }^{3}$ は、込栓・鼻栓を用いた接合部のほぞの引 抜に着目した一連の実験を実施し、初期剛性及び降伏耐力、最大耐 力の評価法を提示している。森迫ら $\left.{ }^{4}\right)$ は、柱 - 貫仕口部試験体につ いて繰り返し載荷実験を行い、その復元力特性をモデル化している。

文献 2)で西村らが指摘しているように、接合部の力学特性に関す る研究の多くは、接合部内のほぞ、込栓、貫、楔を合わせた総体と しての復元力特性を示しており、本来は仕口内部での構造要素間の 応力伝達メカニズムを数学的に表現することで、演繹的に接合部の 復元力特性を評価できる力学モデルを提示することが望ましい。こ の考えに対応寸る研究として、李ら 5) は、柱と貫の相対回転角に応 じためり込み特性に関する実験データから得られためり込み構成則
を用いて、柱 - 貫接合部のモーメント - 回転角関係骨格曲線を予測 する手法を定式化した。船坂、西村 ${ }^{6}$ は、仕口部を仮想剛体と仮想 ばねで表し、木材の局部変形による剛性変化、木材間の摩擦抵抗、 込栓の抵抗を簡易に評価するための力学モデルを提案した。棚橋、 鈴木 7) は、弾塑性パステルナーク・モデルを十字型通し貫仕口の回 転めり込みに適用し、仕口の弾塑性復元力特性の定式化を提案した。 坂田ら $\left.{ }^{8}\right)$ は、等変位全面横圧縮試験のような簡便な実験から得られ る木材の構成則のみを用いて、接合部の曲げモーメント - 回転角関 係を評価できる解析法を提案した。

仕口内部の主要な抵抗要素は木材相互のめり込久抵抗と摩擦抵抗 である。特に、骨組が繰り返し載荷を受ける場合、木材の接触と離 間や、めり込みによる木材の塑性変形が累積される。文献 9)では、 鋁直構面の剛性と許容せん断耐力を算定するための試験方法として、 繰り返しの履歴特性を得ることが必要とされている。仕口の繰り返 し履歴特性を簡便かつ適切に評価できる仕口のモデル化及び解析法 の確立が重要である。木造骨組の繰り返しの履歴特性を解析的に捉 える研究として、松本ら 10)、近藤ら 11)、荒木ら 12)の研究等があるが、 仕口内部での構造要素間の応力伝達メカニズムを取り扱い、かつ繰 り返しの履歴特性を評価できる解析法の研究事例は少ない。

一方、著者ら 13)14) は、仕口内部のめり込久特性を弾塑性ばねで置 換した解析モデルを構築し、木造軸組の繰り返し履歴特性を評価し た。仕口部を剛体とばねで表現する点は文献 6) と同様である。

\footnotetext{
$*$ 関西大学環境都市工学部建築学科 准教授 $\cdot$ 博士 $($ 工学)

Assoc. Prof., Dept. of Architecture, Faculty of Environmental and Urban Eng., Kansai Univ., Dr. Eng.

** (株)エスパス建築事務所 修士 (工学)

$* * *$ 関西大学大学院理工学研究科 大学院生 
本論文は、長ほぞ差し込栓打ち形式の伝統木造仕口を対象として 繰り返し載荷時の履歴特性を解析的に把握することを目的とし、仕 口内部の木材のめり込み特性と摩擦特性を考慮した解析モデルを構 築し、これに基づく変位増分解析法を提案する。めり込み特性は材 料試験から得られる材料特性を用いて評価する。摩擦特性を考慮す る際には、クーロン摩擦の構成則に基づいたみかけのせん断剛性の 概念を新たに導入する。また、柱と差鴨居から構成される $\mathrm{T}$ 字型試 験体の載荷実験を実施し、実験結果と解析結果との比較検討を行う ことにより、解析法の妥当性を確認する。

\section{2. 木材のめり込み特性と摩擦特性を考慮した弾塑性解析法}

\section{1 仕ロの解析モデル}

本論文では、繰り返し載荷を受ける木造骨組において、仕口内部 における木材の接触・離間を簡便にモデル化し、めり込み特性と摩 擦特性を考慮した弹塑性変位増分解析法を展開する。なお、変形は 微小変形の仮定に従うものとする。

仕口にモーメント荷重が作用すると内部では接触面・非接触面が 発生する。本論文では仕口内部の接触面における抵抗要素を、接触 面に対して垂直方向と平行方向に分解して考える。垂直方向はめり 込みによる抵抗が作用する。平行方向は摩擦抵抗やめり込んだ側面 への食い込みによる抵抗などが複雑に作用する 7)。仕口の解析モデ ルの構築に際して、次の仮定を設ける。

- 主材 (梁、柱) 同士の接触面の位置は材軸線に関して分けられ るものとする。

・ めり込み性状は文献 15)のめり込み性状で表されるものとする。 ほぞ及び同付き接触面におけるめり込みは三角形变位めり込み、 込栓及び鼻栓接触面におけるめり込みは等変位めり込みとする。 (図 1(a))

・ 同一樹種の木材同士が接触する面の場合、繊維直交方向のめり 込みのみを考慮し、繊維方向のめり込みは考慮しない。

・ 込栓、鼻栓のように、剛性が異なる木材が接触する面の場合、 剛性が低いほうの木材のめり込みのみを考慮する。

・接触面に対して平行方向の抵抗は、ほぞ及び胴付き接触面のみ を考慮し、込栓及び鼻栓接触面は考慮しない。また、ほぞ幅方向 のほぞ側面 - ほぞ穴接触面の摩擦抵抗は考慮しない。(図 1(b))

・ めり込みによる抵抗は接触面に設ける弾塑性ばねで表現する。 弾塑性ばねは圧縮側のみに作用し引張側には作用しない。

・仕口内部の初期クリアランスは、めり込みを表現した弾塑性ば ねに初期伸びを与えることで表現する。また、楔の打ち込み等に よる初期応力は、弾塑性ばねに初期縮みとそれに対応する初期ば ね力を与えることで表現する。

仕口の解析モデルの考え方を示すため、差鴨居仕口を例として、 想定される接触面とそこで発生しうるめり込みによる圧縮応力度分 布を図 2 に示寸。ほぞ及び胴付き接触面における三角形分布応力度 及び余長部 ${ }^{15)}$ の応力度と、込栓及び鼻栓接触面における等分布応力 度を想定する。3 章で述べる $\mathrm{T}$ 字型試験体の載荷実験において柱を 水平に設置するため、図 2 の水平方向は実験時の方向に合わせて示 している。差鴨居仕口において想定されるめり込みによる圧縮応力 度を集中荷重に置き換える。その作用位置は、ほぞ及び胴付き接触 面では余長部老除く加圧面下の三角形分布応力度の合力作用点とし、
込栓及び鼻栓接触面では等分布応力度の合力作用点とする。荷重作 用位置に弾塑性ばねを配置し、これをめり込みばねと称することと する。めり込みばねの伸びは合力作用点でのめり込み量とする。

接触面に対して平行方向の抵抗については、滑りを伴う摩擦抵抗 と、めり込んだ側面への食い込みによる抵抗などの、滑りを伴わな い抵抗に分解してモデル化する。滑りを伴う摩擦抵抗はクーロン摩 擦の構成則に従うとし、クーロンスライダーで表現する。従って、 その構成則は完全剛塑性型となる。滑りを伴わない抵抗は、それを 構成する要素の総和を代表するものとしてせん断弾性ばねで表現す る。せん断弾性ばねの伸びは、滑りを伴わない、接触面に対して平 行方向の変形として位置づけられる。接触面に対して平行方向の抵 抗は、クーロンスライダーとせん断弾性ばねの直列結合でモデル化 する。これをせん断ばねと称することとし、接触面上に配置してめ り込みばねと連結する。仕口内部における 1 つの接触面の抵抗要素 を表現したばねモデルを図 3 に示す。

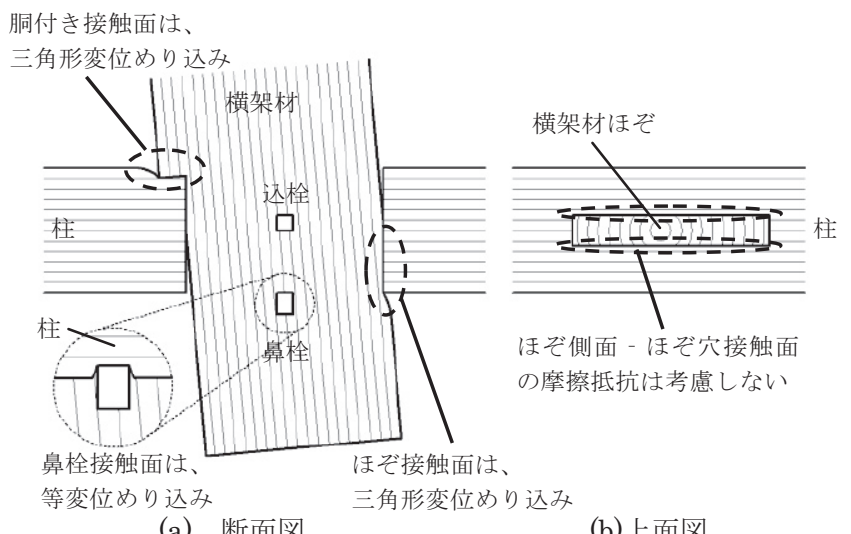
(a) 断面図

(b) 上面図

図 1 想定しためり込み性状

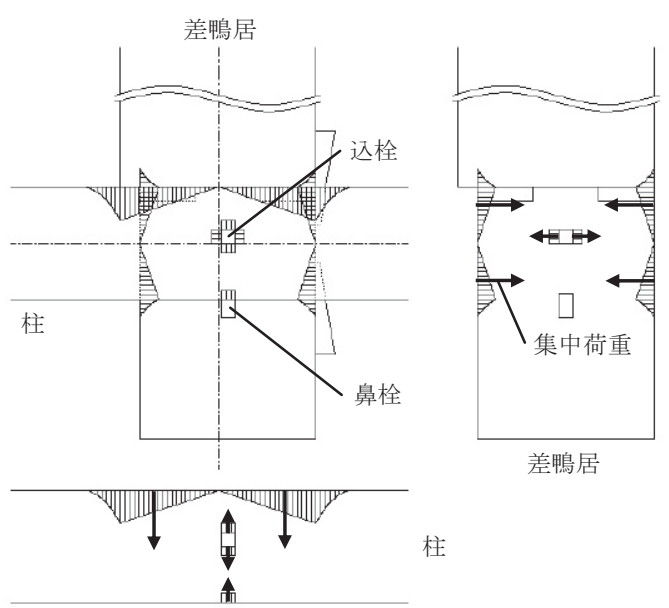

図 2 差鴨居仕口において想定する圧縮応力度分布

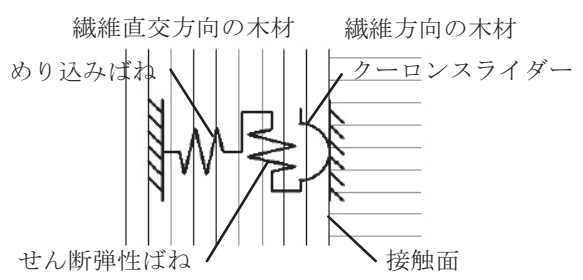

図 3 接触面の抵抗要素を表現したばねモデル 


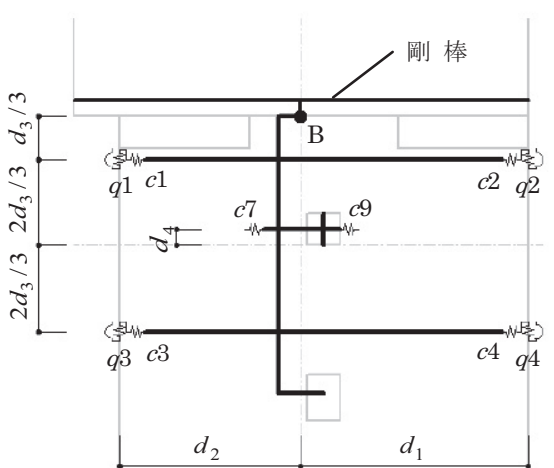

（a）ほぞ部の剛体 - ばねモデル

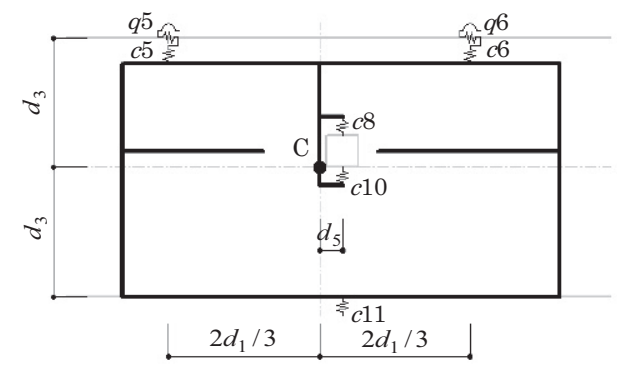

（b）ほぞ穴部の剛体 - ばねモデル

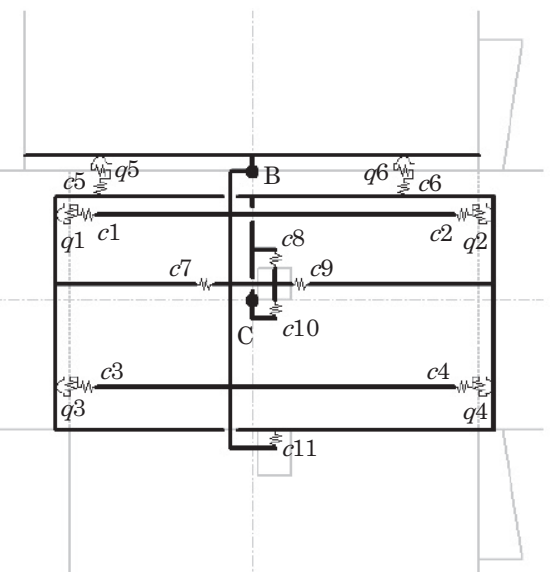

(c) 差鴨居仕口の剛体 - ばねモデル

図 4 差鴨居仕口の剛体 - ばねモデル

各接触面に配置したばねモデルを剛棒で連結し、差鴨居仕口をモ デル化する。これを剛体 - ばねモデルと称することとし、図 4 に示 す。ここで、差鴨居のほぞ周辺部位をほぞ部、柱のほぞ穴周辺部位 をほぞ穴部と称することとする。図 4(a)(b)はそれぞれほぞ部及びほ ぞ穴部の剛体 - ばねモデルを表す。図 4 (c) はほぞ部とほぞ穴部の剛 体 - ばねモデルを、ばねモデルを介して結合した差鴨居仕口の剛体

一ばねモデルを表す。 $c 1 〜 c 11$ はめり込みばね、 $q 1 \sim q 6$ はせん断ば 放を表す。めり込みばね $c 1 \sim c 4$ はほぞ接触面、 $c 5 \sim c 6$ は胴付き接 触面、 $c 7 \sim c 10$ は込栓接触面、 $c 11$ は鼻栓接触面に配置する。せん 断ばね $q 1 \sim q 6$ はめり込みばね $c 1 〜 c 6$ にそれぞれ連結して配置する。 $d_{1} \sim d_{5}$ は材軸線を基準とした、仕口の主要な寸法を表す。ほぞ部 及びほぞ穴部の剛体 - ばねモデルの変位を代表する節点として、そ れぞれ点 $\mathrm{B}, \mathrm{C}$ を設ける。従って、1つの仕口には、ほぞ部に属する 節点とほぞ穴部に属する節点の 2 つが存在する。骨組の主材である 差鴨居、柱は線形弾性の曲げ材として線材置換し、線材の節点と差 鴨居仕口の剛体一ばねモデルの節点を接続する。

\section{2 差鴨居仕口の剛性方程式}

ほぞ部の剛体 - ばねモデルについて、節点 $\mathrm{B}$ の節点力速度ベクト ルを $\dot{\mathbf{p}}_{\mathrm{B}}$ 、節点変位速度ベクトルを $\dot{\mathbf{u}}_{\mathrm{B}}$ 、ばねモデルの配置点の変位 速度べクトルを $\dot{\mathbf{x}}_{\mathrm{B}}$ 、めり込みばね及びせん断ばねのばね力速度べク トルを $\dot{\mathbf{f}}_{\mathrm{B}}$ と表す。ほぞ穴部の剛体 - ばねモデルについても同様に、 節点 $\mathrm{C}$ の節点力速度ベクトルを $\dot{\mathbf{p}}_{\mathrm{C}}$ 、節点変位速度ベクトルを $\dot{\mathbf{u}}_{\mathrm{C}}$ 、 ばねモデルの配置点の変位速度ベクトルを $\dot{\mathbf{x}}_{\mathrm{C}}$ 、めり込みばね及びせ ん断ばねのばね力速度ベクトルを $\dot{\mathrm{f}}_{\mathrm{C}}$ と表す。ここに、( ) は諸状態 量の経路パラメータに対する変化率を意味する。

$\dot{\mathbf{p}}_{\mathrm{B}}, \dot{\mathbf{u}}_{\mathrm{B}}$ 及び $\dot{\mathbf{p}}_{\mathrm{C}}, \dot{\mathbf{u}}_{\mathrm{C}}$ をそれぞれ次式のように表す。

$$
\begin{array}{lll}
\dot{\mathbf{p}}_{\mathrm{B}}=\left\{\begin{array}{lll}
\dot{p}_{\mathrm{B} x} & \dot{p}_{\mathrm{B} y} & \dot{p}_{\mathrm{B} \theta}
\end{array}\right\}, \quad \dot{\mathbf{u}}_{\mathrm{B}}=\left\{\begin{array}{lll}
\dot{u}_{\mathrm{B} x} & \dot{u}_{\mathrm{B} y} & \dot{u}_{\mathrm{B} \theta}
\end{array}\right\}^{\mathrm{T}} \\
\dot{\mathbf{p}}_{\mathrm{C}}=\left\{\begin{array}{llll}
\dot{p}_{\mathrm{C} x} & \dot{p}_{\mathrm{C} y} & \dot{p}_{\mathrm{C} \theta}
\end{array}\right\}^{\mathrm{T}}, \quad \dot{\mathbf{u}}_{\mathrm{C}}=\left\{\begin{array}{lll}
\dot{u}_{\mathrm{C} x} & \dot{u}_{\mathrm{C} y} & \dot{u}_{\mathrm{C} \theta}
\end{array}\right\}^{\mathrm{T}}
\end{array}
$$

$\dot{\mathbf{x}}_{\mathrm{B}}$ と $\dot{\mathbf{u}}_{\mathrm{B}}$ の関係、及び $\dot{\mathbf{x}}_{\mathrm{C}}$ と $\dot{\mathbf{u}}_{\mathrm{C}}$ の関係はそれぞれ次式のように表 される。

$$
\begin{aligned}
& \dot{\mathbf{x}}_{\mathbf{B}}=\mathbf{D}_{\mathbf{B}} \dot{\mathbf{u}}_{\mathbf{B}}, \quad \dot{\mathbf{x}}_{\mathbf{B}}=\left\{\begin{array}{llllll}
\dot{x}_{\mathrm{B}(c 1)} & \cdots & \dot{x}_{\mathrm{B}(c \xi)} & \dot{x}_{\mathrm{B}(q 1)} & \cdots & \dot{x}_{\mathrm{B}(q \eta)}
\end{array}\right\} \\
& \dot{\mathbf{x}}_{\mathrm{C}}=\mathbf{D}_{\mathrm{C}} \dot{\mathbf{u}}_{\mathrm{C}}, \quad \dot{\mathbf{x}}_{\mathrm{C}}=\left\{\begin{array}{llllll}
\dot{x}_{\mathrm{C}(c l)} & \cdots & \dot{x}_{\mathrm{C}(c \xi)} & \dot{x}_{\mathrm{C}(q 1)} & \cdots & \dot{x}_{\mathrm{C}(q))}
\end{array}\right\}
\end{aligned}
$$
ここに、 $\xi$ はめり込みばねの本数、 $\eta$ はせん断ばねの本数である。 $\mathbf{D}_{\mathrm{B}}, \mathbf{D}_{\mathrm{C}}$ はそれぞれ節点 $\mathrm{B}, \mathrm{C}$ と各ばねモデルの配置点の位置関係
より定まる係数行列である（付録 1 ）。

$\dot{\mathbf{p}}_{\mathrm{B}}$ と $\dot{\mathbf{f}}_{\mathrm{B}}$ の関係、及び $\dot{\mathbf{p}}_{\mathrm{C}}$ と $\dot{\mathbf{f}}_{\mathrm{C}}$ の関係は反傾則より次式のように 表される。

$$
\begin{aligned}
& \dot{\mathbf{p}}_{\mathbf{B}}=\mathbf{D}_{\mathrm{B}}^{\mathrm{T}} \dot{\mathbf{f}}_{\mathbf{B}}, \quad \dot{\mathbf{f}}_{\mathbf{B}}=\left\{\begin{array}{llllll}
\dot{f}_{\mathrm{B}(c 1)} & \cdots & \dot{f}_{\mathrm{B}(c \xi)} & \dot{f}_{\mathrm{B}(q 1)} & \cdots & \dot{f}_{\mathrm{B}(q \eta)}
\end{array}\right\}^{\mathrm{T}} \\
& \dot{\mathbf{p}}_{\mathrm{C}}=\mathbf{D}_{\mathrm{C}}^{\mathrm{T}} \dot{f}_{\mathrm{C}}, \quad \dot{\mathbf{f}}_{\mathrm{C}}=\left\{\begin{array}{llllll}
\dot{f}_{\mathrm{C}(c 1)} & \cdots & \dot{f}_{\mathrm{C}(c \xi)} & \dot{f}_{\mathrm{C}(q 1)} & \cdots & \dot{f}_{\mathrm{C}(q \eta)}
\end{array}\right\}^{\mathrm{T}}
\end{aligned}
$$

めり込みばね及びせん断ばねの伸び速度べクトル $\dot{\mathbf{x}}$ は、次式のよ うに表される。

$$
\dot{\mathbf{x}}=\dot{\mathbf{x}}_{\mathbf{B}}-\dot{\mathbf{x}}_{\mathbf{C}}
$$

めり込みばね及びせん断ばねのばね力に関する釣合式より次式が 成り立つ。

$$
\dot{\mathbf{f}}_{\mathrm{B}}+\dot{\mathbf{f}}_{\mathrm{C}}=\mathbf{0}
$$

$\dot{\mathbf{f}}_{\mathrm{B}}$ と $\dot{\mathbf{x}}$ の関係は、フックの法則より次式のように表される。

$$
\dot{\mathbf{f}}_{\mathbf{B}}=\mathbf{K}_{\mathrm{cq}} \dot{\mathbf{x}}, \quad \mathbf{K}_{\mathrm{cq}}=\left[\begin{array}{lllllll}
k_{c 1} & & & & & \\
& \ddots & & & \mathbf{0} & \\
& & k_{c \xi} & & & \\
& & & k_{q 1} & & \\
& \mathbf{0} & & & \ddots & \\
& & & & & k_{q \eta}
\end{array}\right]
$$

ここに、 $\mathbf{K}_{\mathrm{cq}}$ はめり込みばね及びせん断ばねの剛性に関する剛性行 列である。 $k_{c \xi}$ はめり込みばねの剛性であり、 $k_{q \eta}$ はせん断ばねの 剛性である。

以上の式より、差鴨居仕口の剛体 - ばねモデルにおける速度型の 剛性方程式は次式のように表される。

$$
\left\{\begin{array}{l}
\dot{\mathbf{p}}_{\mathrm{B}} \\
\dot{\mathbf{p}}_{\mathrm{C}}
\end{array}\right\}=\left[\begin{array}{c}
\mathbf{D}_{\mathrm{B}}^{\mathrm{T}} \\
-\mathbf{D}_{\mathbf{C}}^{\mathrm{T}}
\end{array}\right] \mathbf{K}_{\mathrm{cq}}\left[\begin{array}{ll}
\mathbf{D}_{\mathrm{B}} & -\mathbf{D}_{\mathbf{C}}
\end{array}\right]\left\{\begin{array}{l}
\dot{\mathbf{u}}_{\mathrm{B}} \\
\dot{\mathbf{u}}_{\mathrm{C}}
\end{array}\right\}
$$

\section{3 めり込みばねの構成則}

解析モデルに使用するめり込みばねの構成則を図 5 に示す。めり 込みばね特性はスリップバイリニア型とし、ばねの伸び $x_{c}$ は圧縮を 負とする。めり込みばねは圧縮側のみに作用し引張側には作用しな い。弾性域、除荷過程をばね状態 I 、塑性域をばね状態 II 、木材の 離間過程をばね状態 III とする。第 1 剛性 $k_{1}$ はめり込み基準式 15$)$ より 求め、第 2 剛性は第 1 剛性の $\alpha$ 倍と寸る。降伏縮みは $x_{c y}$ 、降伏ば ね力は $f_{c y}$ 、残留縮みは $x_{c r}$ と表す。ばね状態ごとのめり込みばね のばね力 $f_{c}$ と伸び $x_{c}$ の関係式を以下に示す。 
· 弾性域、除荷過程（ばね状態 I）

$$
f_{c}=k_{1}\left(x_{c}-x_{c r}\right)
$$

・塑性域（ばね状態 II）

$$
f_{c}=\alpha k_{1}\left(x_{c}-x_{c y}\right)+f_{c y}
$$

・離間過程（ばね状態III）

$$
f_{c}=0, \quad x_{c} \geq x_{c r}
$$

\section{4 せん断ばねの構成則}

解析モデルに使用するせん断ばねの構成則を図 6 に示す。 2.1 節 で述べたように、せん断ばねはクーロンスライダーとせん断弾性ば ねの直列結合であるから、その構成則はめり込みばねのばね力 $f_{c}$ が 一定のとき完全弾塑性型となる。せん断弾性ばねの剛性を $k_{s}$ とする と、せん断ばねの剛性 $k_{q}$ は弾性域では $k_{q}=k_{s}$ となる。せん断ばね のばね力 $f_{q}$ は圧縮を負とし、 $f_{c}<0$ のときのみ作用する。摩擦係数 を $\mu$ とし、せん断ばねのばね力 $f_{q}$ と伸び $x_{q}$ の関係式を以下に示す。

$$
\begin{aligned}
& \dot{f}_{q}=0, \quad\left\{\begin{array}{l}
\text { if } f_{q}=-\mu f_{c} \quad \text { and } \quad \dot{x}_{q} \geq 0 \\
\text { if } \quad f_{q}=\mu f_{c} \quad \text { and } \quad \dot{x}_{q} \leq 0
\end{array}\right.
\end{aligned}
$$

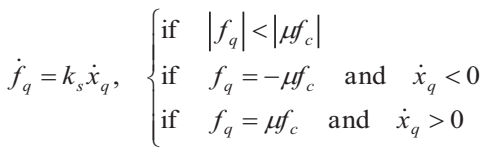

\section{5 めり込みばねのばねカの変動を考慮したみかけのせん断剛性}

仕口の変形に伴いめり込みばねのばね力 $f_{c}$ は変動するため、最大 摩擦力 $\mu f_{c}$ も変動する。変動する $f_{c}$ に対してもせん断ばねの構成則 を満たす必要がある。本論文では、せん断ばねについて、せん断弾 性ばねの伸びとクーロンスライダーの滑りを合成したものに関する みかけのせん断剛性の概念を導入する。めり込みばねの縮みに伴っ てせん断ばねが縮む場合を例として、みかけのせん断剛性の概念図 を図 7 に示寸。今、せん断ばねの状態が点 $\mathrm{P}\left(x_{q}, f_{q}\right)$ にあり、 $f_{q}=\mu f_{c}$ を満たしている場合を考える。仕口の変形に伴って、せん断ばねの 縮み速度が $\dot{x}_{q}$ 、めり込みばねのばね力速度が $\dot{f}_{c}$ のとき、クーロン
摩擦の構成則を満たし続けるならば、せん断ばねのばね力速度は $\dot{f}_{q}=\mu \dot{f}_{c}$ とならなければならない。せん断ばねの状態点はせん断弾 性ばねの縮みとクーロンスライダーの滑りが同時に生じた結果とし て経路 PR を辿ると考える。これはせん断弾性ばねが縮む過程 PQ とクーロンスライダーが滑る過程 QR の合成として把握できる。経 路 PR の傾きをみかけのせん断剛性 $k_{a}$ として表す。滑りが発生する 場合におけるせん断ばねのばね力速度 - 伸び速度関係を以下に示す。

$$
\begin{aligned}
& \dot{f}_{q}=k_{a} \dot{x}_{q} \\
& k_{a}=\mu \dot{f}_{c} / \dot{x}_{q}
\end{aligned}
$$

式(17)からみかけのせん断剛性 $k_{a}$ はせん断弾性ばねの剛性 $k_{s}$ に依 存しないことが確認できる。

めり込みばねの縮みの進行に伴って、せん断ばねの状態点の経路 PR のような移動が連続的に生じる。本論ではめり込みばねの構成 則は区分的線形であると仮定しているので、せん断ばねの状態点も 区分的線形経路を辿る。

変位増分解析において、めり达みばねのばね力 $f_{c}$ が変動する場合 のせん断ばねの剛性 $k_{q}$ は繰り返し収束計算によって求められる。変 位増分解析の第 $n$ ステップにおける $k_{q}$ の決定に関するアルゴリズ ムを以下に示す。ここで $\Delta$ は変位増分に対するばね力及び伸びの増 分を示す。

[1] せん断ばねの剛性の初期值として $k_{q}=k_{s}$ と仮定する。

[2] 剛性方程式を解き、めり込みばねの伸び増分 $\Delta x_{c}$ 及びせん断ば 漦の伸び増分 $\Delta x_{q}$ を求め、めり込みばねのばね力増分 $\Delta f_{c}$ 、せん 断ばねのばね力増分 $\Delta f q$ を求める。

[3] 増分後の最大摩擦力 $\mu f_{c}^{(n)}$ 、せん断ばねのばね力 $f_{q}^{(n)}$ を求める。

[4] $\mu f_{c}^{(n)}$ と $f_{q}^{(n)}$ の大小関係を比較し、整合する $k_{q}$ を新たに仮定す る。

［5］すべてのせん断ばねが構成則を満たすまで [2]～[4]を繰り返 す。

めり込みばねの縮みに伴ってせん断ばねが縮む場合を例として、上 記アルゴリズムの [4]における $k_{q}$ の仮定方法を図 8 に示す。めり込

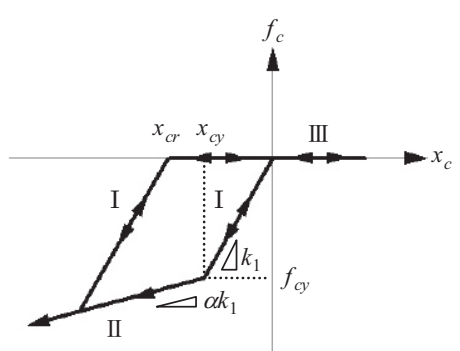

図 5 めり込みばねの構成則

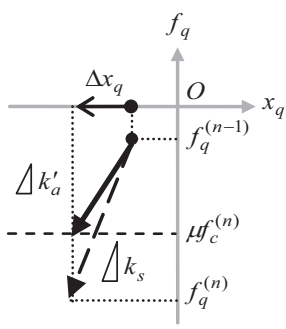

(a)

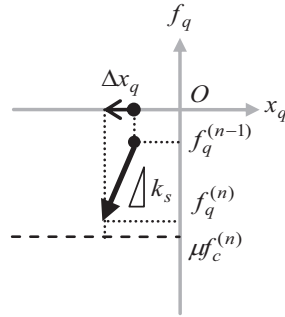

(b)

$\left|f_{q}^{(n)}\right| \leq\left|\mu f_{c}^{(n)}\right|$ and $k_{q}=k_{s}$

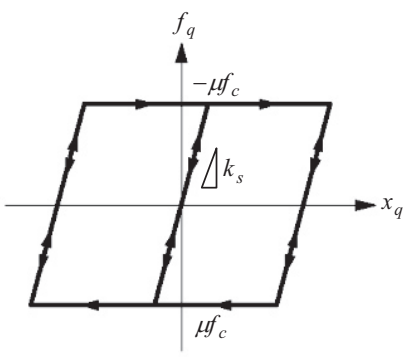

図 6 せん断ばねの構成則

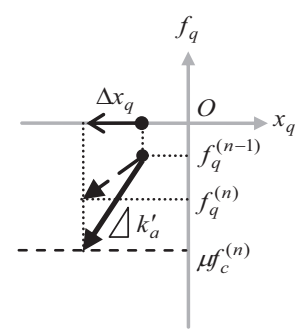

(c)

$\left|f_{q}^{(n)}\right| \leq\left|\mu f_{c}^{(n)}\right|$ and $k_{q} \neq k_{s}$

図 8 せん断ばねの剛性 $k_{q}$ の仮定方法

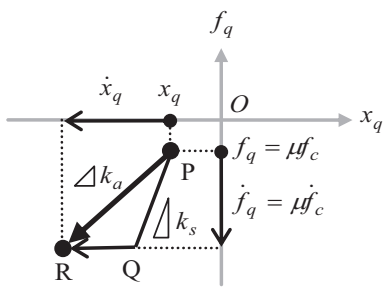

図 7 みかけのせん断剛性 $k_{a}$

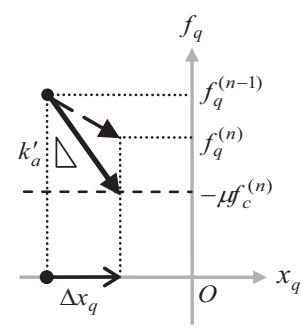

(d)

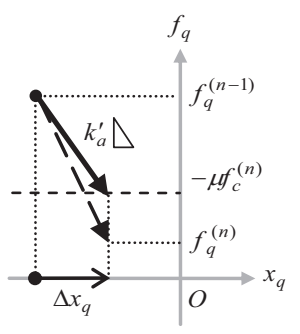

(e) $\left|f_{q}^{(n)}\right|>\left|\mu f_{c}^{(n)}\right|$

$\left|f_{q}^{(n)}\right| \leq\left|\mu f_{c}^{(n)}\right|$ 
みばねのばね力 $\left|f_{c}\right|$ が増加する場合において、 $\left|f_{q}^{(n)}\right|>\left|\mu f_{c}^{(n)}\right|$ のとき、 $\left|f_{q}^{(n)}\right|=\left|\mu f_{c}^{(n)}\right|$ を満たすようなみかけのせん断剛性 $k_{a}^{\prime}$ (ダッシュは仮 定の意味）を求め、せん断ばねの剛性を $k_{q}=k_{a}^{\prime}$ とする（図 8(a)）。 $\left|f_{q}^{(n)}\right| \leq\left|\mu f_{c}^{(n)}\right|$ かつ $k_{q}=k_{s}$ のとき、滑りが発生しないためせん断ばね の剛性を $k_{q}=k_{s}$ とする (図 8(b))。| $f_{q}^{(n)}|\leq| \mu f_{c}^{(n)} \mid$ かつ $k_{q} \neq k_{s}$ のとき、 同様にみかけのせん断剛性 $k_{a}^{\prime}$ を求め、せん断ばねの剛性を $k_{q}=k_{a}^{\prime}$ とする (図 8(c))。めり込みばねのばね力 $\left|f_{c}\right|$ が減少する場合におい ても同様で、 $\left|f_{q}^{(n)}\right|>\left|\mu f_{c}^{(n)}\right|$ または $\left|f_{q}^{(n)}\right| \leq\left|\mu f_{c}^{(n)}\right|$ のとき、 $\left|f_{q}^{(n)}\right|=\left|\mu f_{c}^{(n)}\right|$ を満たすようなみかけのせん断剛性 $k_{a}^{\prime}$ を求め、せん断ばねの剛性を $k_{q}=k_{a}^{\prime}$ とする (図 $\left.8(\mathrm{~d})(\mathrm{e})\right)$ 。

めり込みばねのばね力 $f_{c}$ が弾性域で変動する場合について、せん 断ばねの状態点の履歴の概念図を図 9 に示す。 $\Delta x_{c}$ と $\Delta x_{q}$ が同符号 の場合、経路 $\mathrm{ABCA}$ の履歴となる。経路 $\mathrm{AB}$ は $\left|f_{c}\right|$ が増加する過程 を示し、せん断ばねの剛性 $k_{q}$ はみかけのせん断剛性 $k_{a}^{(\mathrm{AB})}$ となる。 経路 BCA は $\left|f_{c}\right|$ が減少する過程を示寸。そのうち経路 BC は変位増 分反転後のせん断ばねの弾性域に対応し、 $k_{q}$ はせん断弾性ばねの剛 性 $k_{s}$ となる。この間にせん断ばねのばね力 $f_{q}$ の符号が反転し、点 $\mathrm{C}$ で再びクーロン摩擦の構成則を満たす。経路 CA では、 $k_{q}$ はみかけ のせん断剛性 $k_{a}^{(\mathrm{CA})}$ となる。 $\Delta x_{c}$ と $\Delta x_{q}$ が異符号の場合は、経路 ADEAの履歴となる。

\section{3. $\mathrm{T}$ 字型試験体の載荷実験}

\section{1 試験体}

本論文で提案する解析法の有効性を確認するため、文献 14)で実 施した実験を以下に示す。一般的な伝統木造構法の一つである差鴨 居仕口を対象として、載荷実験を実施した。

試験体は柱と差鴨居で構成される $\mathrm{T}$ 字型試験体である。図 10 に 試験体及び変位の計測位置（ $\delta$ は変位計を意味する）を示す。試験 体の各寸法は伝統木造軸組で一般的に多く使用されている寸法とし た。柱と差鴨居の部材長さは、既往の研究 13)の実験結果より曲げモ ーメントの反曲点を参考にして決定した。差鴨居仕口は長ほぞ差し 込栓打ち形式で鼻栓と楔を設けている。仕口の詳細を図 11 に示す。 樹種については、差鴨居、柱にはスギ、込栓、鼻栓、楔にはカシを 用いている。スギの縦圧縮ヤング係数は JIS ${ }^{16}$ )に基づいた縦圧縮試 験の結果より、 $7.4 \times 10^{3}\left(\mathrm{~N} / \mathrm{mm}^{2}\right)$ であった。

\section{2 載荷方法}

変位制御の正負交番載荷とし、載荷はデジタルジャッキが伸びる 方向を正とする。載荷サイクルは反転変形角 $\pm 1 / 600, \pm 1 / 450, \pm$ $1 / 300, \pm 1 / 200, \pm 1 / 150, \pm 1 / 100, \pm 1 / 75, \pm 1 / 50(\mathrm{rad})$ で、各サイ クルの繰り返し回数は 3 回である。その後 $\pm 1 / 15(\mathrm{rad})$ で 1 回のみ繰 り返し載荷し、最後に正方向のみ $1 / 10(\mathrm{rad})$ まで載荷したのち $0(\mathrm{rad})$ まで除荷する。

\section{3 測定方法}

ロードセルで荷重を、変位計 1,2 で水平変位を、変位計 3,4 で仕 口における柱と差鴨居の相対変位を、変位計 5,6 でピン支点の浮き 上がりを計測した。変形角、仕口における差鴨居のモーメント、柱 に対する差鴨居の相対回転角、引き抜け量を評価する式を以下に示 す。

変形角:

$$
\gamma=\left(\delta_{1}-\delta_{2}\right) / L_{12}-\left(\delta_{5}-\delta_{6}\right) / L_{56}
$$

モーメント：

$$
M=P \cdot L_{b}
$$

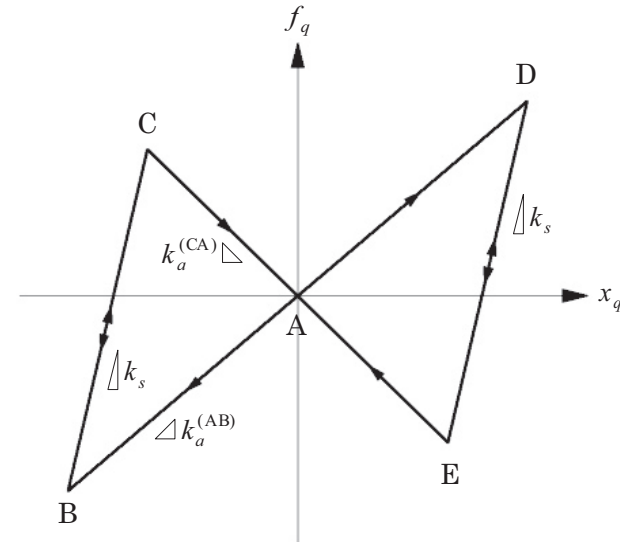

図 9 めり込みばねのばね力が変動する場合のせん断ばねの状態点 の履歴

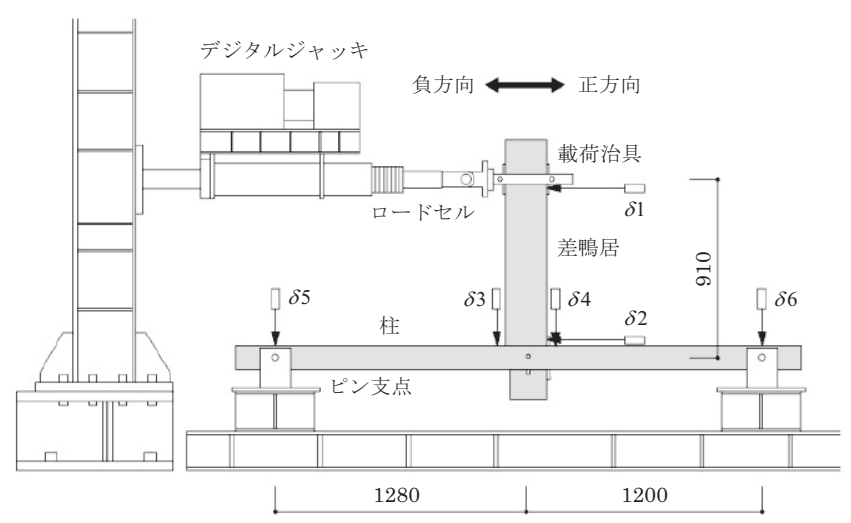

図 10 試験体及び変位の計測位置（単位：mm）

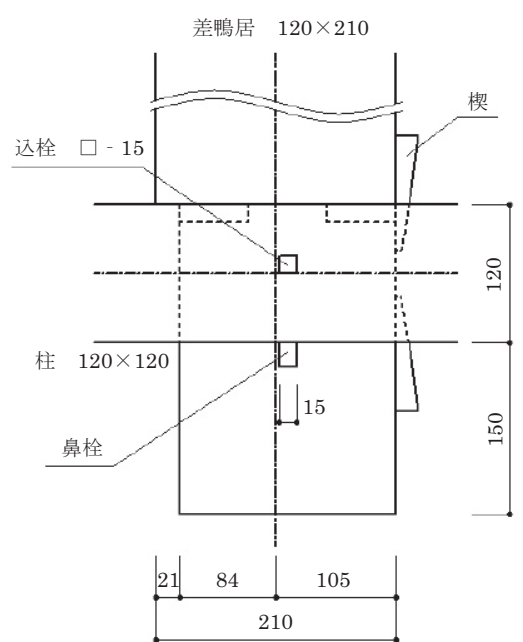

仕口 側面図

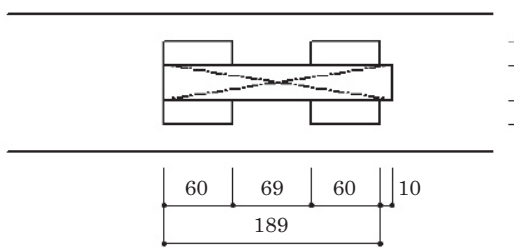

柱 上面図 
相対回転角：

$$
\theta=\left(\delta_{3}-\delta_{4}\right) / L_{34}
$$

引き抜け量 :

$$
\delta=\left(\delta_{3}+\delta_{4}\right) / 2
$$

$\delta_{i}$ : 変位計 $i$ で測定した変位 $\quad L_{i j}$ : 変位計 $i, j$ の測定位置間隔 $P$ : ロードセルで測定した荷重 $L_{b}:$ 載荷点と柱心の間隔

\section{4 実験結果}

1）復元力特性

載荷実験の結果として、復元力特性を図 12 に示す。 $\pm 1 / 150(\mathrm{rad})$ サイクル以下の小変形領域では、 $2 、 3$ 回目の履歴ループは 1 回目の 履歴ループと同じ経路を辿り、 $\pm 1 / 150(\mathrm{rad}) を$ 超える大変形領域で は 1 回目の履歴ループにおいて過去に経験した最大変形までの履歴 は前サイクルの載荷過程における 2,3 回目の履歴ループと同じ経路 を辿った。繰り返し履歴の回数が増えるにつれて、立ち上がり勾配 が低下した。これはめり込みによる塑性残留変形によって仕口内部 のクリアランスや楔の緩みが生じたことによると考えられる。変形 角が大きくなるにつれて、載荷過程の剛性が徐々に低下した。この 剛性低下の主要な要因は、ほぞ及び胴付き接触面でのめり込みによ る局所的な塑性変形であると考えられる。仕口の変形については、 ほぞ及び同付き接触面でのめり込みと楔の変形を確認したが、鼻栓 の曲げ破壊やほぞのせん断破壊等の終局状態には至らなかった。

2)引き抜け量

引き抜け量 - 変形角関係を図 13 に示す。各反転変形角の引き抜け 量は、 $\pm 1 / 50(\mathrm{rad})$ で $1 \mathrm{~mm}$ 程度、 $\pm 1 / 15(\mathrm{rad})$ で $3 \mathrm{~mm}$ 程度、+ $1 / 10(\mathrm{rad})$ で $6 \mathrm{~mm}$ 程度であった。

\section{4. 弾塑性解析}

本論文で展開した、木材のめり込久特性と摩擦特性を考慮した解 析モデルを用いた解析法に基づく変位増分解析を実施し、実験結果 のシミュレーションを行う。

\section{1 解析概要}

$\mathrm{T}$ 字型試験体の線材モデルを図 14 に示す。図 14 中の数字は節点 番号を表し、括弧付き数字は部材番号を表す。線材モデルは 4 つの 部材と 5 つの節点から構成される。部材(1)は差鴨居、部材(2)は仕 口、部材(3)(4)は柱を表す。節点 1 の水平変位 $u_{1}$ を変位制御する変 位増分解析を行い、太矢印の方向を正と寸る。載荷サイクルは反転 変形角 $\pm 1 / 150, \pm 1 / 50, \pm 1 / 15(\mathrm{rad})$ とし、正方向のみ $1 / 10(\mathrm{rad})$ ま で解析を行う。 3.4 節で述べたように、小変形領域では $2 、 3$ 回目の 履歴ループは 1 回目の履歴ループと同じ経路を辿り、大変形領域で は 1 回目の履歴ループにおいて過去に経験した最大変形までの履歴 は前サイクルの載荷過程における 2,3 回目の履歴ループと同じ経路 を辿ることから、解析における繰り返し回数は各サイクルについて 1 回とする。

\section{2 差鴨居仕口の剛体 - ばねモデル}

差鴨居仕口の剛体 - ばねモデルを図 15 に、めり込みばね及びせん 断ばねの配置及び力学特性を表 1,2 に示す。座標は、ほぞ穴部の剛 体 - ばねモデルの節点 4 を原点とし、柱の初期材軸線方向に $x$ 軸を 設ける。表 1,2 において、 $x$ 方向に作用寸るばねの配置には $y$ 座標 を、 $y$ 方向に作用するばねの配置には $x$ 座標を示している。めり込 みばねの第 1 剛性 $k_{1}$ はめり込夕基準式 ${ }^{15}$ ) より求め、第 2 剛性に関 するパラメータ $\alpha$ は JIS ${ }^{16)}$ に基づいた部分圧縮試験の結果より 0.10 とする (付録 2 )。降伏縮み $x_{c y}$ は同じ試験結果より得られた降
伏ひずみ 0.01 に対応するものとして求めた。 $\mathrm{T}$ 字型試験体の載荷実 験時には楔の打ち込み等による初期応力を測定していないため、本 解析においてはこれを考虑していない。せん断弾性ばねの剛性 $k_{s}$ は 材料構成則に基づく定量的な評価が困難なため、めり込みばねの剛 性が接触面積に依存することから、 $k_{s}$ は接触面積 $A$ に比例すると仮 定して、以下の式で求めることとする。

$$
k_{s}=\beta A
$$

復元力特性において、 $k_{s}$ は変位増分反転後の除荷剛性のみに影響を 及ぼす (付録 2 )。従って $\beta$ については、実験結果の復元力特性にお ける反転変形角 $+1 / 50(\mathrm{rad})$ 後の除荷履歴を線形近似し、その除荷剛 性にフィッテングさせて $\beta=11.4\left(\mathrm{~N} / \mathrm{mm}^{3}\right)$ を得た。

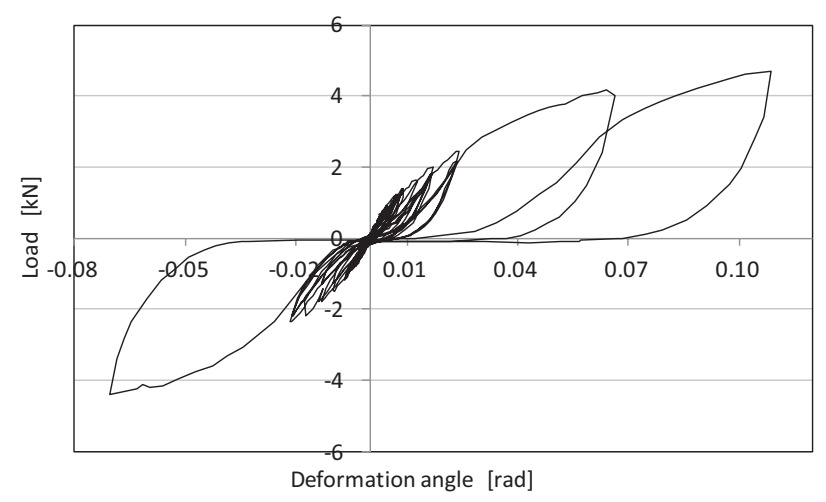

図 12 荷重 - 変形角関係

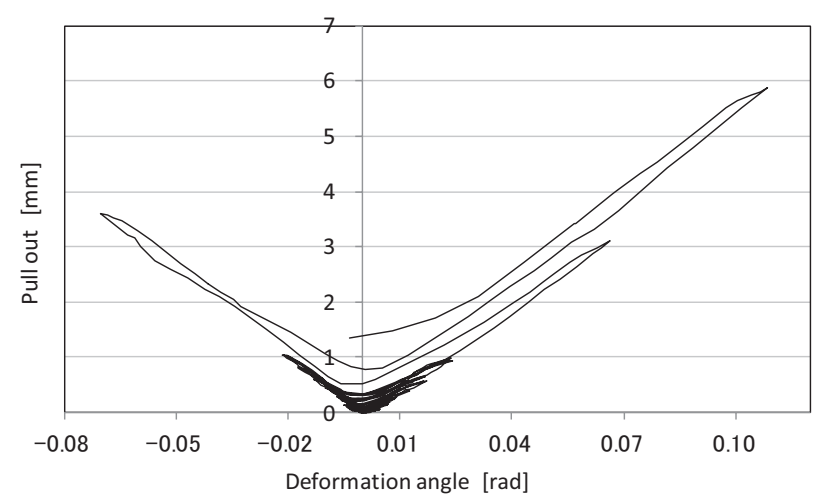

図 13 引き抜け量 - 変形角関係

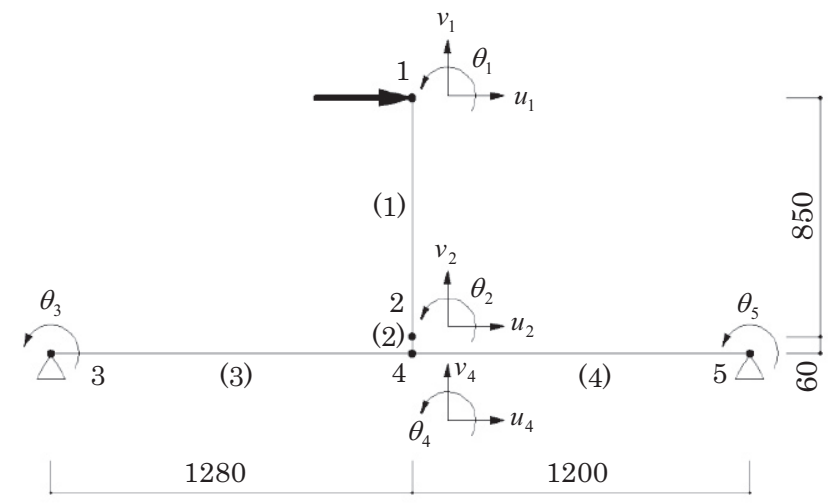

図 $14 \mathrm{~T}$ 字型試験体の線材モデル（単位：mm） 


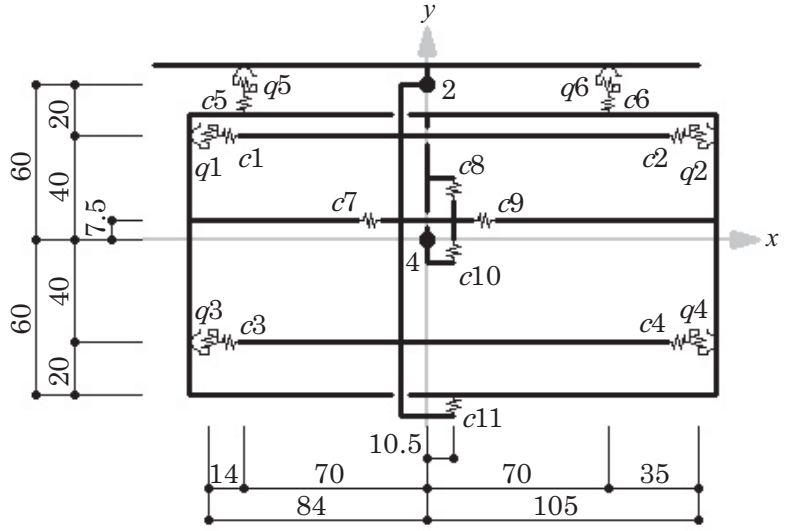

図 15 差鴨居仕口の剛体 - ばねモデル（単位：mm）

表 1 めり込みばねの配置及び力学特性

\begin{tabular}{|c|c|c|c|c|c|}
\hline & ばね番号 & 作用方向 & $\begin{array}{l}\text { 座標 } \\
(\mathrm{mm})\end{array}$ & $\begin{array}{c}k_{1} \\
\left(\times 10^{3} \mathrm{~N} / \mathrm{mm}\right)\end{array}$ & $\begin{array}{c}x_{c y} \\
(\mathrm{~mm}) \\
\end{array}$ \\
\hline \multirow{11}{*}{$\begin{array}{l}\text { め } \\
\text { り } \\
\text { 込 } \\
\text { み } \\
\text { ば } \\
\text { ね }\end{array}$} & $c 1$ & $x$ & 40.0 & 10.06 & -1.89 \\
\hline & $c 2$ & $x$ & 40.0 & 10.06 & -1.89 \\
\hline & $c 3$ & $x$ & -40.0 & 8.29 & -1.89 \\
\hline & $c 4$ & $x$ & -40.0 & 8.29 & -1.89 \\
\hline & $c 5$ & $y$ & -70.0 & 22.03 & -1.20 \\
\hline & $c 6$ & $y$ & 70.0 & 22.03 & -1.20 \\
\hline & $c 7$ & $x$ & 7.5 & 1.53 & -0.87 \\
\hline & $c 8$ & $y$ & 10.5 & 8.88 & -0.45 \\
\hline & $c 9$ & $x$ & 7.5 & 1.53 & -0.87 \\
\hline & $c 10$ & $y$ & 10.5 & 6.66 & -0.60 \\
\hline & $c 11$ & $y$ & 10.5 & 6.66 & -0.60 \\
\hline
\end{tabular}

表 2 せん断ばねの配置及び力学特性

\begin{tabular}{|c|c|c|r|r|r|}
\hline \multirow{4}{*}{} & ばね番号 & 作用方向 & $\begin{array}{c}\text { 座標 } \\
(\mathrm{mm})\end{array}$ & $\begin{array}{c}k_{s} \\
\left(\times 10^{3} \mathrm{~N} / \mathrm{mm}\right)\end{array}$ & $\begin{array}{c}A \\
\left(\mathrm{~mm}^{2}\right)\end{array}$ \\
\hline \multirow{4}{*}{\begin{tabular}{c} 
せ \\
断 \\
\cline { 2 - 6 } \\
\cline { 2 - 6 } \\
\cline { 2 - 6 } \\
\cline { 2 - 6 }
\end{tabular}} & $q 1$ & $y$ & -84.0 & 20.52 & 1800 \\
\cline { 2 - 6 } & $q 3$ & $y$ & 105.0 & 20.52 & 1800 \\
\cline { 2 - 6 } & $q 5$ & $x$ & 60.0 & 20.52 & 1800 \\
\cline { 2 - 6 } & $q 6$ & $x$ & 60.0 & 20.52 & 1800 \\
\hline
\end{tabular}

スギの縦圧縮ヤング係数は実験を行った $\mathrm{T}$ 字型試験体と同じ 7.4 $\times 10^{3}\left(\mathrm{~N} / \mathrm{mm}^{2}\right)$ とする。横圧縮ヤング係数は文献 17$)$ より縦圧縮ヤン グ係数の $1 / 25$ とする。木材の摩擦係数 $\mu$ は文献 18)より 0.54 とす る(付録 2$)$ 。

\section{3 状態量の評価}

図 14 より、節点 $i$ の節点変位を $\left(\begin{array}{lll}u_{i} & v_{i} & \theta_{i}\end{array}\right)$ と表す。

1）変形角

$\mathrm{T}$ 字型試験体の変形角は次式で評価する。

$$
\gamma=u_{1} / L_{b}
$$

2) モーメント

仕口における差鴨居のモーメントは次式で評価する。

$$
M=p \cdot L_{b} \quad p: \text { 節点 } 1 の \text { 節点力 }
$$

3）相対回転角

仕口における柱に対する差鴨居の相対回転角は、差鴨居仕口の剛 体 - ばねモデルにおいて、節点 4 に対する節点 2 の相対回転量とし、 次式で評価する。

$$
\theta=\theta_{2}-\theta_{4}
$$

4）引き抜け量

引き抜け量は差鴨居仕口の剛体 - ばねモデルにおいて、節点 4 に 対する節点 2 の相対鉛直変位とし、次式で評価する。

$$
\delta=v_{2}-v_{4}
$$

5）回転中心

回転中心は差鴨居仕口の剛体 - ばねモデルにおいて、節点 4 に対 する相対水平変位速度と相対鉛直変位速度が発生せず、相対回転角 速度のみが発生する、ほぞ部の剛体 - ばねモデルに属する点とする。 以下に回転中心の導出過程を示す。

節点 4 に対する節点 2 の相対節点変位速度 $\left(\dot{u}_{24}, \dot{v}_{24}, \dot{\theta}_{24}\right)$ は、 $\ell_{24}$ を 節点 2 と節点 4 の距離とすると、以下のように表される。

$$
\begin{aligned}
& \dot{u}_{24}=\dot{u}_{2}-\dot{u}_{4}-\ell_{24} \dot{\theta}_{4} \\
& \dot{v}_{24}=\dot{v}_{2}-\dot{v}_{4} \\
& \dot{\theta}_{24}=\dot{\theta}_{2}-\dot{\theta}_{4}
\end{aligned}
$$

ほぞ部の剛体 - ばねモデルに属する任意の点 $\mathrm{R}(x, y)$ の節点 4 に対 する相対変位速度 $\left(\dot{u}_{R 4}, \dot{v}_{R 4}\right)$ は、以下のように表される。

$$
\begin{aligned}
& \dot{u}_{R 4}=\dot{u}_{24}-\left(y-\ell_{24}\right) \dot{\theta}_{24} \\
& \dot{v}_{R 4}=\dot{v}_{24}+x \dot{\theta}_{24}
\end{aligned}
$$

従って、回転中心の定義により $\left(\dot{u}_{R 4}, \dot{v}_{R 4}\right)=(0,0)$ が満たされる位置と して回転中心の座標 $(x, y)$ は、以下の式により求められる。

\section{4 解析結果}

$$
\begin{aligned}
& x=-\dot{v}_{24} / \dot{\theta}_{24} \\
& y=\dot{u}_{24} / \dot{\theta}_{24}+\ell_{24}
\end{aligned}
$$

\section{1）復元力特性}

解析の結果として、復元力特性を実験結果と合わせて図 16 に示す。 ただし、実験結果は載荷サイクル 1/10(rad)におけるそれぞれ 1 回目の履歴ループのみを取り出して いる。また、後に考察する力学的な特徵点を $\mathrm{a} \sim \mathrm{f}$ 点で示す。図 16 より、実験結果と解析結果は耐力、剛性ともに概ね一致しているこ とが確認できる。ただし、 $\pm 1 / 150(\mathrm{rad})$ サイクル時の解析結果につ いては、耐力、剛性ともに実験結果を下回っている。この理由は、 楔の打ち込み等による初期応力を考慮していないことが要因と考え られる。

また、せん断ばねの効果を確認するため、せん断ばねをすべて除 いた場合の解析結果を実験結果と合わせて図 17 に示す。図 16 のせ ん断ばねありの解析結果と比較して、剛性、耐力の低下がみられる。 このことから、仕口内部における接触面に対して平行方向の抵抗は 復元力特性に大きな影響を与えることが確認できる。

2）モーメント-相対回転角関係

モーメント - 相対回転角関係を実験結果と合わせて図 18 に示す。 ただし、実験結果は載荷サイクル $\pm 1 / 150 ， \pm 1 / 50 ， \pm 1 / 15 ，+$ 1/10( $\mathrm{rad})$ におけるそれぞれ 1 回目の履歴ループのみを取り出してい る。図 18 より、モーメントー相対回転角関係においても実験結果 と解析結果は良い対応を示している。

3）めり込みばね及びせん断ばねのばね力 - 伸び関係

解析結果の例として、図 19 にめり込みばね $c 3$ のばね力 - 伸び関 係を、図 20 にめり込みばね $c 3$ に連結されたせん断ばね $q 3$ のばね 力 - 伸び関係を示す。また、せん断ばねのばね力 - 伸び関係と復元 力特性及びめり込みばねのばね力 - 伸び関係との対応を示すために、 


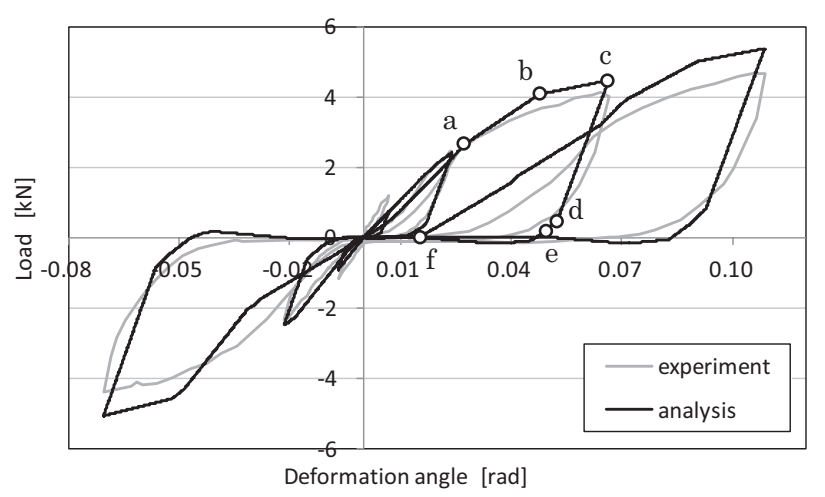

図 16 荷重 - 変形角関係（せん断ばねあり）

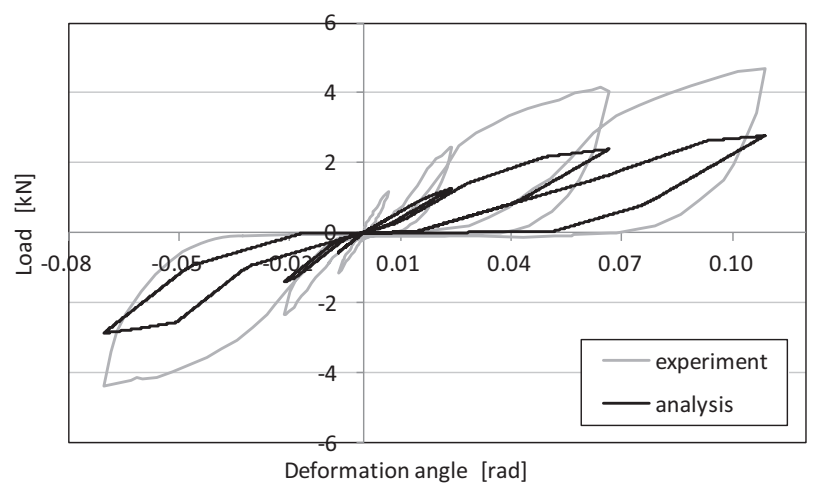

図 17 荷重 - 変形角関係（せん断ばねなし）

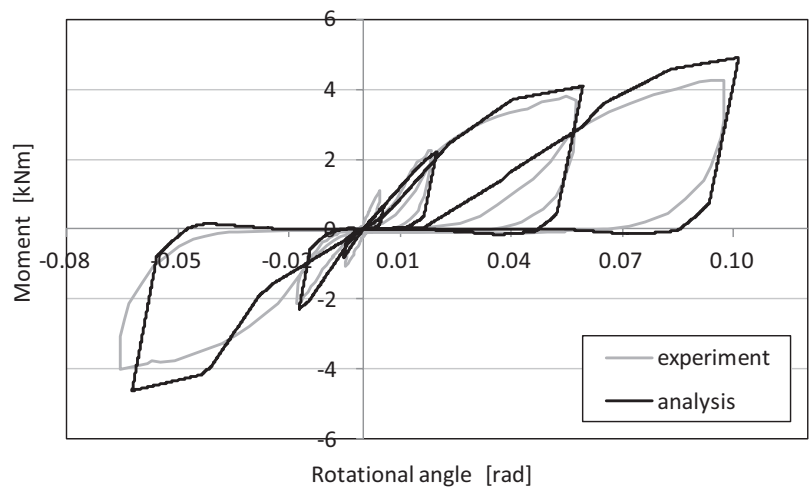

図 18 モーメント - 相対回転角関係（せん断ばねあり）

$+1 / 15(\mathrm{rad})$ サイクルにおいて対応する力学的な特徵点を図 16、図 19、 図 20 に $\mathrm{a} \sim \mathrm{f}$ 点で示す。図 20 中の $\mathrm{a}$ 点と $\mathrm{e}$ 点における剛性変化は、 他のばねの剛性変化に伴うものである。 $\mathrm{b}$ 点ではめり込みばね $c 3$ (ほ ぞ接触面でのめり込み）が降伏し、復元力の剛性及びせん断ばね $q 3$ のみかけのせん断剛性が低下した。 $\mathrm{c}$ 点は反転変形角に対応してい る。経路 $\mathrm{cd}$ はせん断ばねの弾性域に対応し、 $\mathrm{d}$ 点で再びクーロン摩 擦の構成則が満たされる。 $\mathrm{f}$ 点では、めり込みばね $c 3$ のばね力がゼ ロになり (ほぞの離間)、せん断ばね $q 3$ のばね力がゼロになる。こ れらの分析から、めり込みばねのばね力の変動に伴い、せん断ばね のばね力も変動し、めり込みばねのばね状態の変化によってみかけ

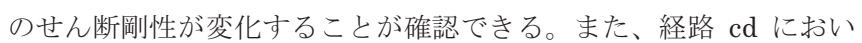

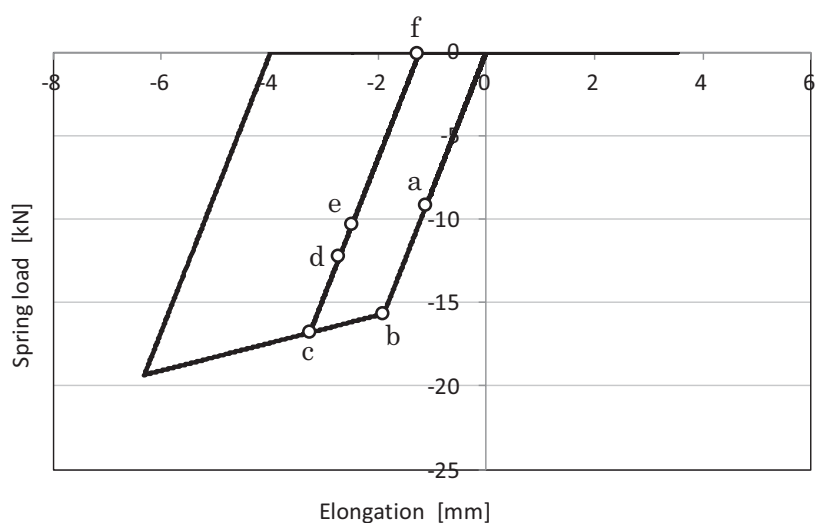

図 19 めり込みばね $c 3$ のばね力 - 伸び関係

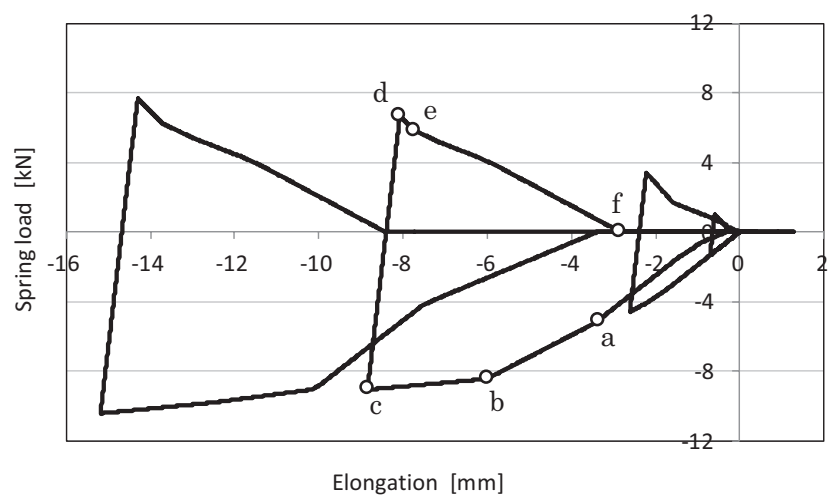

図 20 せん断ばね $q 3$ のばね力 - 伸び関係

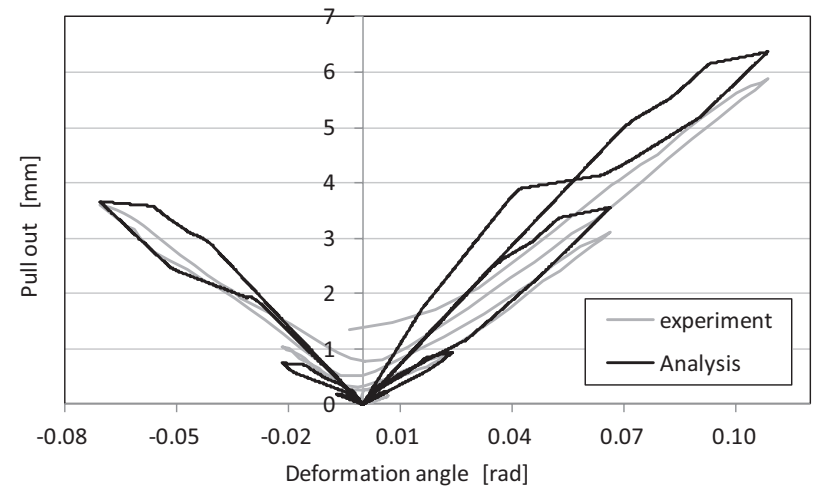

図 21 引き抜け量 - 変形角関係

てせん断ばねのばね力の符号が反転することによって、変位増分反 転後にみられる復元力特性の急激な荷重低下を再現できていること が確認できる。

4）引き抜け量

差鴨居の引き抜け量 - 変形角関係を実験結果と合わせて図 21 に 示す。ただし、実験結果は載荷サイクル $\pm 1 / 150 ， \pm 1 / 50 ， \pm 1 / 15$, $+1 / 10(\mathrm{rad})$ におけるそれぞれ 1 回目の履歴ループのみを取り出して いる。各反転変形角の引き抜け量は実験結果と良い対応を示してい る。

5）回転中心

変形角 $0 \rightarrow+1 / 50(\mathrm{rad})$ 及び $0 \rightarrow-1 / 50(\mathrm{rad})$ の載荷過程を例として、 


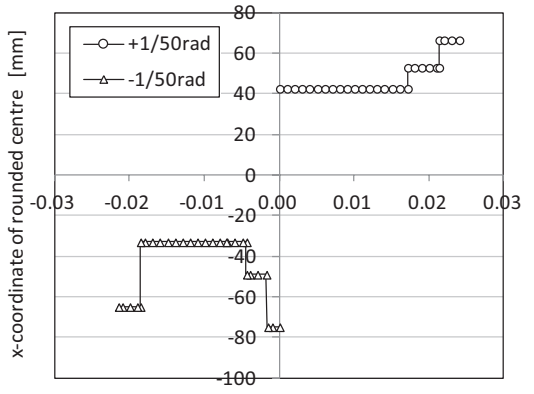

Deformation angle [rad]

図 22 回転中心の $x$ 座標 $(0 \rightarrow+1 / 50 \mathrm{rad}, 0 \rightarrow-1 / 50 \mathrm{rad})$

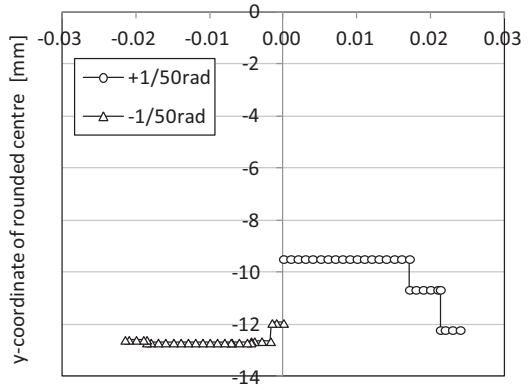

Deformation angle [rad]

図 23 回転中心の $y$ 座標 $(0 \rightarrow+1 / 50 \mathrm{rad}, 0 \rightarrow-1 / 50 \mathrm{rad})$

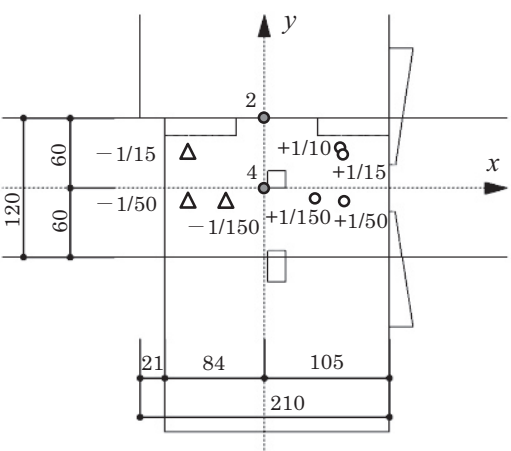

図 24 反転変形角における回転中心の位 置 (単位 : $\mathrm{mm}$ )
回転中心の $x$ 座標 - 変形角関係を図 22 に、回転中心の $y$ 座標 - 変 形角関係を図 23 に示寸。回転中心の座標は、差鴨居仕口の剛体 ばねモデルの節点 4 を原点とし、柱の初期材軸線方向に $x$ 軸を設け る。図 22,23 より、変形角が大きくなるとともに、回転中心が移動 している様子が確認できる。回転中心が不連続に移動する要因は、 めり込みばねのばね状態の変化である。

また、反転変形角における回転中心の位置を図 24 に示寸。図 24 中の算用数字は差鴨居仕口の剛体 - ばねモデルにおける節点番号を 表す。図 24 中の記号○は反転変形角が正のときにおける回転中心 の位置を表し、記号 $\triangle$ は反転変形角が負のときにおける回転中心の 位置を表す。回転中心の位置とあわせて反転変形角の值も示寸。回 転中心の $x$ 座標は反転変形角が正のとき正、負のとき負となる。回 転中心の $y$ 座標は反転変形角 $\pm 1 / 150(\mathrm{rad}) 、 \pm 1 / 50(\mathrm{rad})$ では負とな るが、 $\pm 1 / 15(\mathrm{rad}) 、+1 / 10(\mathrm{rad})$ では正となる。

\section{5 考察}

$\mathrm{T}$ 字型試験体の載荷実験の結果と、解析結果との比較検討を行っ た。復元力特性では、実験結果と解析結果は良い対応を示しており、 本論文で提案した解析法の妥当性を確認することができた。また、 復元力特性における変位増分反転後の急激な荷重低下をせん断ばね のばね力の符号が反転することによって再現できた。モーメント 相対回転角関係と引き抜け量では、本解析法が各種状態量を容易に 評価できることを示した。せん断ばねのばね力 - 伸び関係では、め り込みばねのばね力の変動に伴い、せん断ばねのばね力も変動する ことを確認した。回転中心の解析結果では、めり込みばねのばね状 態が変化することによって、回転中心が移動する様子を表現できた。

本解析法の特徴の 1 つは、骨組解析において 1 つの仕口について 2 つの節点を有する剛体 - ばねモデルを用いることである。ただし、 めり込みばねの配置や剛性の評価においては、簡便のため、一つの 接触面について正負載荷に抵抗するばね要素をそれぞれ一つずつ代 表させて配置しており、また材軸線に関して対称のめり込み抵抗状 態を仮定しているので、実際のめり込みの状態とは必ずしも一致し ないはずである。従って、複雑な仕口形状や引き抜け等によるめり 込み応力度分布の変化を考慮するためには、一つの接触面について 複数のばね要素を設置するなどの工夫が必要になると考えられる。 種々の仕口形状についてばね要素の配置やその適切な剛性評価法を 構築することが今後の課題といえる。

また、せん断弾性ばねの剛性 $k_{s}$ については、 $\mathrm{T}$ 字型試験体の載荷
実験の復元力特性に基づいて決定した。従って、せん断弾性ばねの 力学特性の適切な評価法も今後の課題である。

\section{5. まとめ}

長ほぞ差し込栓打ち形式の伝統木造仕口を対象として繰り返し載 荷時の履歴特性を解析的に把握することを目的とし、めり込みによ る抵抗と仕口内部における接触面に対して平行方向の抵抗を考慮し た解析モデルを構築し、仕口の繰り返し履歴特性を評価できる変位 増分解析法を提案した。本論文で得られた成果は以下のとおりであ る。

（1）仕口内部の接触面における抵抗要素を、接触面に対して垂直方 向と平行方向に分解して考えた。垂直方向はめり込みによる抵抗 を考慮し、平行方向は滑りを伴う摩擦抵抗と、めり込んだ側面一 の食い込みによる抵抗などの、滑りを伴わない抵抗を考慮した。 仕口内部の木材の接触・離間を簡便にモデル化するために、めり 込みによる抵抗を弾塑性ばね（めり込みばね）で、接触面に対し て平行方向の抵抗を完全弾塑性ばね（せん断ばね）で表現し、1 つの仕口について 2 つの節点を有する剛体 - ばねモデルを構築し た。

（2）めり込み抵抗については、材料試験から得られる材料特性を用 いて評価した。接触面に対して平行方向の抵抗については、めり 込みによる変動する圧縮応力度に対してもクーロン摩擦に基づい た構成則を満たすために、みかけのせん断剛性の概念を導入した。 これらに基づいて、仕口の繰り返し履歴特性を評価できる変位増 分解析法を提案した。

（3） $\mathrm{T}$ 字型試験体の載荷実験の結果に対して、提案した解析法に基 づくシミュレーションを行った。復元力特性において、実験結果 と解析結果は良い対応を示しており、本論文で提案した解析法の 妥当性を確認することができた。

（4）仕口のモーメント - 相対回転角関係、引き抜け量及び回転中心 を例として、本解析法は各種状態量を容易に評価できることを示 した。

\section{参考文献}

1）前野将輝，鈴木祥之：伝統木造軸組の実大実験による柱 - 横架材接合部 の曲げモーメント抵抗に関する研究，日本建築学会構造系論文集， No.601, pp.113-120, 2006.3

2）西村督，後藤正美，鈴木祥之:木造軸組構法における長ほぞ込栓打ち接合 
部の応力伝達に関する実験的研究, 日本建築学会構造系論文集, Vol.75, No.658, pp.2197-2204, 2010.12

3）松本拓也, 多幾山法子, 林康裕: 柱 - 差鴨居接合部の力学特性に関する実 験的研究, 日本建築学会構造系論文集, Vol.77, No.675, pp.747-754, 2012.5

4) 森迫清貴, 三宅祐子, 北尾聡子: 伝統木造架構の柱 - 貫仕口部の繰り返し 栽荷実験に基づく履歷曲線のモデル化，構造工学論文集，Vol.51B， pp.503-512, 2005.3

5）李東潤, 荒木慶一, 遠藤俊貴, 吉田亘利, 上谷宏二：めり込み実験に基づ <伝統木造柱 - 貫半剛接合特性の推定, 日本建築学会構造系論文集, Vol.73, No.631, pp.1577-1584, 2008.9

6）船坂佳伸, 西村督: 木材の局部変形を考慮した長ほぞ込栓打ち仕口部の 簡易力学モデル, 日本建築学会大会学術講演梗概集, C-1（構造 III）, pp.325-326, 2011.8

7）棚橋秀光, 鈴木祥之: 伝統木造仕口の回転めり込久弾塑性特性と十字型 通し貫仕口の定式化, 日本建築学会構造系論文集, Vol.76, No.667, pp.1675-1684, 2011.9

8）坂田弘安, 山崎義弘, 宇田川洋隆, 大橋好光 : 曲げせん断を受ける長ほぞ 差し込栓打ち接合部の力学的挙動に関する研究, 日本建築学会構造系論 文集, Vol.77, No.671, pp.45-54, 2012.1

9) (財) 日本住宅・木材技術センター: 木造軸組工法住宅の許容応力度設 計（2008 年版）, p 570, 2008.12

10）松本慎也, 藤谷義信, 野島千里, 岩佐裕一, 樫原健一: 伝統木造建築物の 地震応答解析, 構造工学論文集, Vol.49B, pp.251-257, 2003.3

11）近藤一夫, 光井周平, 河内武: ハイブリッド型応力法による伝統的木造架 構の弹塑性解析（その 1) 有限変形効果を考慮した定式化と柱の傾斜復 元力に関する数值実験，構造工学論文集, Vol.54B, pp.201-210, 2008.3

12）荒木康弘, 腰原幹雄, 五十田博, 河合直人, 坂本功: 木造住宅の接合部破 壊を考慮した大変形時の静的挙動に関する解析的研究, 日本建築学会構 造系論文集, Vol.74, No.637, pp.527-535, 2009.3

13）錦田謙介, 八尾眞太郎, 桝井健: 引き抜けとめり込みを考慮した仕口モデ ルを用いた木造軸組の解析, 日本建築学会大会学術講演梗概集, C-1（構 造林) , pp.81-82, 2010.9

14）野村良太, 八尾眞太郎, 桝井健, 高木利季: 差鴨居構法における単方差 三方差仕口の構造性能, 日本建築学会大会学術講演梗概集, C-1 (構造 III), pp.327-328, 2011.8

15）稲山正弘：木材のめりこみ理論とその応用 - 勒性に期待した木質ラーメ ン接合部の耐震設計法に関する研究 - , 東京大学学位論文, 1991.12

16）日本規格協会：木材の試験方法（JIS Z 2101）, 2009.7

17）（社）日本建築構造技術者協会：木造建築構造の設計, $\mathrm{p} 21$, （株）オー 么社, 2004.8

18）（独）森林総合研究所：木材工業ハンドブック, pp.128-129, 丸善（株）, 2004.3

\section{付録 1}

2.2 節で示した節点 $\mathrm{B}, \mathrm{C}$ と各ばねモデルの配置点の位置関係より定まる係 数行列 $\mathbf{D}_{\mathbf{B}}, \mathbf{D}_{\mathbf{C}}$ について、図 4 のばねモデル配置 $(\xi=11, \eta=6)$ の場合に おける具体的な表記を以下に示す。

$\mathbf{D}_{\mathbf{B}}=\left[\begin{array}{rrr}1 & 0 & d_{3} / 3 \\ -1 & 0 & -d_{3} / 3 \\ 1 & 0 & 5 d_{3} / 3 \\ -1 & 0 & -5 d_{3} / 3 \\ 0 & 1 & -2 d_{1} / 3 \\ 0 & 1 & 2 d_{1} / 3 \\ 1 & 0 & d_{3}-d_{4} \\ 0 & -1 & -d_{5} \\ -1 & 0 & -\left(d_{3}-d_{4}\right) \\ 0 & 1 & d_{5} \\ 0 & -1 & -d_{5} \\ 0 & 1 & -d_{2} \\ 0 & 1 & d_{1} \\ 0 & -1 & d_{2} \\ 0 & -1 & -d_{1} \\ 1 & 0 & 0 \\ -1 & 0 & 0\end{array}\right], \quad \mathbf{D}_{\mathbf{C}}=\left[\begin{array}{rrr}1 & 0 & -2 d_{3} / 3 \\ -1 & 0 & 2 d_{3} / 3 \\ 1 & 0 & 2 d_{3} / 3 \\ -1 & 0 & -2 d_{3} / 3 \\ 0 & 1 & -2 d_{1} / 3 \\ 0 & 1 & 2 d_{1} / 3 \\ 1 & 0 & -d_{4} \\ 0 & -1 & -d_{5} \\ -1 & 0 & d_{4} \\ 0 & 1 & d_{5} \\ 0 & -1 & -d_{5} \\ 0 & 1 & -d_{2} \\ 0 & 1 & d_{1} \\ 0 & -1 & d_{2} \\ 0 & -1 & -d_{1} \\ 1 & 0 & -d_{3} \\ -1 & 0 & d_{3}\end{array}\right]$

\section{付録 2}

めり込みばねの第 2 剛性に関するパラメータ $\alpha$ 、せ九断弹性ばねの剛性 $k_{s}$ に関するパラメータ $\beta$ 、摩擦係数 $\mu$ が解析結果の復元力特性に与える影響を 比較する。

$\alpha=0.02,0.10,0.50$ の場合の復元力特性を付図 1 亿示寸。付図 1 より、 $\alpha$ が 大きい場合めり込みばねの第 2 剛性が高くなるため、変形角土 $1 / 50(\mathrm{rad})$ を超 える大変形領域において耐力、剛性が高くなることが確認できる。

$\beta=7.0,11.4,17.0\left(\mathrm{~N} / \mathrm{mm}^{3}\right)$ の場合の復元力特性を付図 2 に示す。付図 2 上り、 復元力特性において $\beta$ は載荷時の履歷には影響を及ぼさず変位増分反転後 の除荷剛性のみに影響し、 $\beta$ が大きいほど除荷剛性も高くなることが確認で きる。

$\mu=0.45,0.54,0.65$ の場合の復元力特性を付図 3 に示寸。 $\mu$ が大きい場合、 解析の全領域において剛性、耐力が高くなることが確認できる。

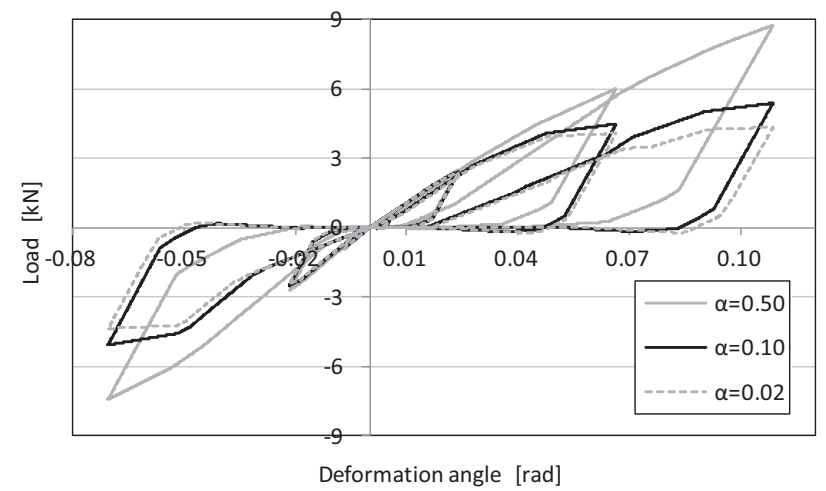

付図 1 荷重 - 変形角関係 $(\alpha$ による比較 $)$

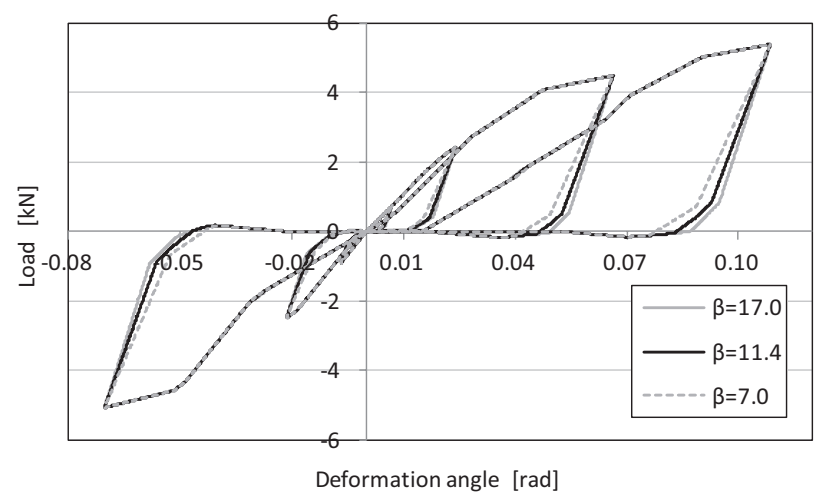

付図 2 荷重 - 変形角関係 $\left(\beta\left[\mathrm{N} / \mathrm{mm}^{3}\right]\right.$ による比較 $)$

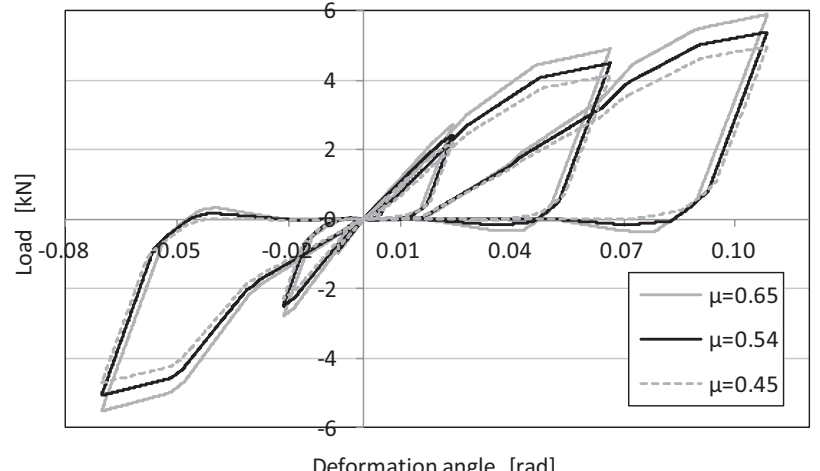

付図 3 荷重 - 変形角関係（ $\mu$ による比較）

（2012年 9 月 10 日原稿受理，2013年 1 月10日採用決定） 